\title{
1. What is the role of new technologies in tensions in intellectual property?*
}

\author{
Margaret Ann Wilkinson
}

\section{THE CHALLENGE}

Much scholarship in recent years has focused on the intersection of intellectual property law and technology. And, indeed, of late there have been important intellectual property issues raised in the face of technological developments. However, of course, 'correlation is not causation'. The thesis of this chapter is that, while the changing technological environment is certainly highlighting tensions in intellectual property law, both within nation states and globally, it is an earlier structural change that actually created the fundamental tensions in intellectual property law. Specifically, nineteenth-century developments in corporate law fundamentally altered the effect of the then extant laws that form the basis for modern intellectual property law. However, the impact on patent, trademark and copyright of these Victorian-era changes to the business environment has not been explicitly recognised or identified. The effect has thus remained largely unaddressed for over a century, creating the tensions that are now being made increasingly manifest as the information age, with its technological advances, proceeds. The chapter concludes with an illustration of the danger of lack of analytic clarity about the limits of intellectual property law or, at least, lack of analytic rigour about the reality of what "intellectual property" has become.

* Paper first presented at the 33rd Congress of the Association for the Advancement of Teaching and Research in Intellectual Property [ATRIP], Montpellier, France, July 2014. Subsequent editing was with the assistance of law students Adrita Shah Noor and Colin Hyslop and support from Social Sciences \& Humanities Council of Canada Grant 435-2016-1638). The law in this chapter is current to August 2018. 


\section{RE-CONCEPTUALISING THE PROBLEM}

The developments in corporate law that are pivotal to this thesis are, first, the legal separation of companies from their individual owners, and, second, the legal recognition of corporations as legal persons in their own right. The first development occurs in the mid-nineteenth century, through such legal landmarks as the United Kingdom's 1844 Joint Stock Companies Act ${ }^{1}$ and Canada's pre-Confederation 1850 enactment by the United Provinces of Canada of An Act to Provide for the Formation of Incorporated Joint Stock Companies for Manufacturing, Mining, Mechanical or Chemical Purposes. ${ }^{2}$ The second development occurs at the end of the nineteenth century, through vehicles such as the 1886 American decision in Santa Clara Cty $v$ Southern Pacific RR $\mathrm{Co}^{3}$ and the 1897 British decision in Salomon $v$ A Salomon \& Co Ltd. ${ }^{4}$

The origins of the three major forms of intellectual property law, patent, copyright and trademark, all lie centuries before the two monumental landmarks in the development of modern corporate law (and modern economies) took place. It is important to consider the origins of patent, copyright and trademark in the context of their own times, when the separation of business from consumer was much less obvious than it is now. Up until the mid-nineteenth century, when the modern legal separation of a corporation from its owners occurred, inventors, authors and creators were exclusively individuals who, in turn, could only engage in business with other individuals - and a business's goodwill was only the goodwill of the individual or individuals operating it.

The Statute of Monopolies, ${ }^{5}$ in creating the original British exception preserving monopolies for "inventors" in the early seventeenth century, speaks in terms of individuals. ${ }^{6}$ The early eighteenth-century Statute of Anne $^{7}$ legislating copyright monopolies was similarly speaking about business opportunities for individual authors. In its first section it distinguishes "authors" from those to whom authors may have transferred

\footnotetext{
11844 (UK) 7 \& 8 Vict, c110.

2 SC 1850, c 28.

3118 US 394 (1886).

4 [1897] AC 22 (HL) (Eng).

5 The Statute of Monopolies, 21 Jac I, c. 3 (1624)

6 The key s.6, speaks of the rights of "the true and first inventor".

7 An Act for the Encouragement of Learning, by vesting the Copies of Printed Books in the Authors or Purchasers of such Copies, During the Times therein mentioned, 1709, 8 Anne, c. 19.
} 
copies, including booksellers, printers, or those who have purchased or acquired copies. ${ }^{8}$

The important statement in the late eighteenth-century American Constitution about patents and copyright was similarly created contemplating only individual authors and inventors, in a business environment comprised only of individuals acting as sole proprietorships or in partnerships of individuals: "The Congress shall have the power ... To promote the Progress of Science and useful Arts, by securing for limited Times to Authors and Inventors the exclusive Right to their respective Writings and Discoveries". ${ }^{9}$ As the American Constitution so eloquently articulates, patent and copyright were designed by governments as mechanisms to provide incentives to individuals to spur them to creativity and innovation, in turn producing public benefits through dissemination of information by individuals acting in sole proprietorships or partnerships of individuals, thereby promoting "progress". In the economic and political life of their times, the "public interest" was politically synonymous with the national interest of the nation promoting the protection of patents and copyright works. ${ }^{10}$ See Figure 1.1.

At the end of the nineteenth century four great international information treaties emerged: the Treaty concerning the formation of the General Postal Union (1874), ${ }^{11}$ the International Telegraph Convention

8 Section 1 spoke of "the Author of any Book or Books already printed, who hath not transferred to any other the Copy or Copies of such Book ..." and identified the work with its author, though the copyright was not always to be held by that author. See Lyman Ray Patterson, Copyright in Historical Perspective, Nashville: Vanderbilt Press (1968), ch 7.

9 US Constitution Art $1 \S 8 \mathrm{cl} 8$ (1787).

10 In a clear and unanimous statement in $\mathrm{CCH}$ Canadian Ltd. v Law Society of Upper Canada (2004 SCC 13, [2004] 1 S.C.R. 339), at para 23, the Supreme Court of Canada provides an authoritative definition of the public interest in copyright: "promoting the encouragement and dissemination of works of the arts and intellect and obtaining a just reward for the creator". See further background on this concept in Margaret Ann Wilkinson, "National Treatment, National Interest and the Public Domain" (2003-2004) 23 U Ottawa L \& Tech J 48 and Victoria Owen, "Who Safeguards the Public Interest in Copyright in Canada?" (2012) 59 J of the Copyright Society of the USA, 803-842.

11 Known as the Treaty of Bern, 19 Stat. 577. In 1878 the treaty became that of the Universal Postal Union, see http://www.loc.gov//law/help/us-treaties/ bevans/m-ust000001-0051.pdf. Now an organ of the United Nations, see http:// www.upu.int. 


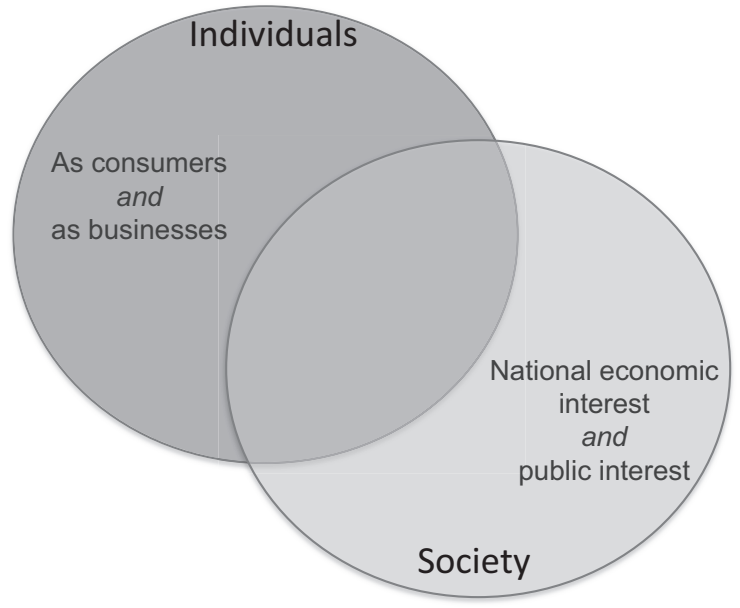

Figure 1.1 Stakeholders represented in the creation of patent and copyright

(1865), ${ }^{12}$ the Paris Convention for the Protection of Industrial Property (1883), ${ }^{13}$ and the Berne Convention for the Protection of Literary and Artistic Works (1886). ${ }^{14}$ In the latter two treaties, Paris and Berne, the concepts which later became collectively known as "intellectual property" were given multilateral expression and it is the two then most legally mature intellectual property devices, patent protection (in Paris) and copyright protection (in Berne), that were given fullest expression. The final firm fixation of intellectual property within the framework of public international law occurred when the formerly independent institutions of international intellectual property governance, the Paris Union and the Berne Union, became part of the United Nations in the third quarter of the twentieth century. ${ }^{15}$

12 search.itu.int/history/HistoryDigitalCollectionDocLibrary/4.1.43.fr200.pdf. Now the International Telecommunications Convention, an organ of the United Nations, see https://www.itu.int.

1320 March 1883 [Paris].; last revised in 1967 and amended in 1979 [see 21 UST 1583, 828 UNTS 305]. Since 1967 governed by the World Intellectual Property Organization (WIPO), an organ of the United Nations since 1970. The treaty in its original 1883 form is available in French at http://www.wipo.int/ wipolex/en/treaties/text.jsp?file_id=287780.

149 September 1886, 828 UNTS 2891. [Berne].

15 Convention Establishing the World Intellectual Property Organization, United Nations General Assembly (1967) 14 July 1967, 828 UNTS 3. 
The less definitive treatment of trademarks (in the original Paris) provides evidence that international consensus at the time was least robust around it. This is consistent with other historical evidence. For instance, the earlier constitutional expression in the United States concerning legal devices that would later be collectively considered as part of "intellectual property" 16 did not deal with trademark because trademark at the time was governed in the original common law jurisdiction, Britain, if at all, exclusively by custom (not law) ${ }^{17}$ and so the American colonies would have seen no need to deal with it in a constitution assigning legislative powers as between the new federal and state governments. Nearly a century later, even though British courts had given legal force to the protection of trademark through recognising the tort of passing off by $1842,{ }^{18}$ Canada omitted trademarks in its founding constitution, just as the United States had, but included allocation of legislative power over patents and copyright works (in this case likely because before Confederation trademarks were not protected by statute in one of the founding provinces but only at common law at the time). ${ }^{19}$

The legal recognition of trademarks occurred in the mid-nineteenth century, ${ }^{20}$ roughly concurrent with the emergence of the legal device of

16 In the nineteenth century, patent and trademark had become collectively known as "industrial property". The concept of "intellectual property", denoting industrial property and copyright, was a later construct. In the Convention Establishing the World Intellectual Property Organization, supra note 15, s.2(viii) defines "intellectual property" as including the rights relating to "literary, artistic and scientific works", "performances of performing artists, phonograms, and broadcasts", "inventions in all fields of human endeavor", "scientific discoveries", "industrial designs", "trademarks, service marks, and commercial names and designations", "protection against unfair competition", and "all other rights resulting from intellectual activity in the industrial, scientific, literary or artistic fields". Note that the concept of protection of business confidences is not explicitly included.

17 The first statement of the modern tort of passing off occurs in Perry $v$ Truefitt (1842), 6 Beav 66 at 73; 49 ER 749 at 752.

18 Ibid.

19 Constitution Act, 1867, 1867 (UK) 30 \& 31 Vict, c. 3, reprinted in RSC 1985, App II, No 5, ss 91(22) [patent] and (23) [copyright]. Nova Scotia has no trademark statute. One later federal statute on trademark, the Unfair Competition Act, 1932 (SC 1932, c. 38), focused on unfair competition in its title. 1954 returned trademark to the title (see current Trade-marks Act (RSC 1985, c T-13)).

20 The first civil law recognition of the third bulwark of the "classic" intellectual property triad, trademarks, occurred roughly simultaneously with the common law recognition: in France's Manufacture and Goods Mark Act, 1857 (French law no 4,720 of 23 June 1857). 
the corporation (noted above), the latter allowing a business to be conducted on a basis apart from either the individual as a sole proprietor or individuals operating together as partners. However, as in the cases of protection of patents and copyright works, the legal foundations of trademark law, in both common and civil law traditions, predate the late nineteenth-century legal recognition of corporations as persons in law. Coincidentally, the original international patent (Paris 1883) and copyright (Berne 1886) agreed texts (created by representatives of governments) appear either before or just simultaneous with the beginnings of recognition of corporations as separate persons in law (1886 in American courts, 1897 in British, as described above).

Probably in no small measure due to the internationalisation of patent and copyright law through adoption of treaty texts, ${ }^{21}$ a certain understanding of copyright and patent law has become doctrine in the twenty-first century. ${ }^{22}$ Modern intellectual property theorising and rhetoric has continued to consider consumers and businesses as one single interest, ${ }^{23}$ apparently simply because, when patent and copyright were first created, consumers and businesses were all individuals. This chapter seeks to challenge this understanding.

\section{AN EARLY CHALLENGE TO CLASSIC CONCEPTIONS EMERGES}

Although copyrights, patents and trademarks have become firmly recognised as being legal devices that give rise to private rights (specified market monopolies) for public purposes, this has not always been the

21 Sam Rickertson, The Berne Convention for the Protection of Literary and Artistic Works, 1886-1986, London: Centre for Commercial Studies, Queen Mary University, (1987), 79-80 confirms that "[d]espite relatively limited membership, the geographical sweep of the new [Berne] Union was considerable when account is taken of the colonial possessions of France, Germany, Italy, Belgium, Spain and the UK". The Paris Union included all these same members plus the United States.

22 "Doctrine" in the sense connoted by the Oxford English Dictionary definition 2(b) of "doctrine" as: "That which is taught or laid down as true concerning a particular subject or department of knowledge ...; a belief, theoretical opinion; a dogma, tenet".

23 See Abraham Drassinower, "A Rights-based View of the Idea/Expression Dichotomy in Copyright Law" (2003) 16 Cdn J of Law \& Jurisprudence 3 who, for example, conceives of all members of society as either currently creators or future creators. 
case. When copyright and patent rights first arose (before the nineteenth century), those "private rights" were originally only the rights of individuals - because all business was conducted on an individual basis through sole proprietorships or individuals acting together in partnerships. It will be argued in this chapter that once individual and corporate interests were separated during the nineteenth century - and diverged even more during the twentieth - the concept of "balance" in intellectual property needed to be re-conceptualised in terms of "balancing" three sets of interests: those of individuals (as it is undeniably individuals' cognitive activity which produces creativity and innovation), those of corporations (which have come to dominate in terms of both ownership, including that of new technologies, and influence upon economies), ${ }^{24}$ and that of the public. This transformed way of thinking did not emerge. ${ }^{25}$ Nevertheless, although the changed business and societal playing field that resulted from the legal recognition of corporations as legal persons has not led to a fundamental re-examination of patent, copyright or trademark protection, it would appear that the consequences of the changes wrought by the legal separation of the individual and corporate business were detected almost immediately in some quarters and led to early attempts to address a fundamentally changed copyright environment.

Not long after the corporate form of business entity entered the European business environment, there emerged in Europe a new form of rights in creativity - the moral rights. ${ }^{26}$ Rights of this new type, which

24 For example, Pat Choate specifically identifies "two US corporate CEOs, John R. Opel of IBM and Edmund T. Pratt Jr. of Pfizer pharmaceuticals" as the progenitors of the TRIPS Agreement. See Pat Choate, Hot Property: The Stealing of Ideas in an Age of Globalization, New York: Knopf (2005), 16.

25 This author suspects that the rigidities of the industrial mechanisms for dissemination of information (for instance, the need for presses) masked the entrance of the new corporate players (since individuals had previously occupied similar roles) and blurred the increase in the number of types of players. With the new technologies again enabling individuals, the corporate interests are themselves bringing their dominance (and separation from individual interests) into sharp relief.

26 Even as early as 1928 it was noted, in the Records of the [Berne Union] Conference convened in Rome May 7 to June 2, 1928, at II. Reports of Sub-Committees, in 1. Sub-Committee on Moral Rights, that "it is henceforth beyond doubt that the creator of a literary and artistic work retains rights in the product of his intellectual effort that are above and outside all agreements on disposal. Those rights, which for want of a more adequate expression are called moral rights, are distinguished from economic rights, and assignment of the latter 
were proposed by European member states for inclusion in the international Berne Convention, included the rights of paternity, integrity, divulgation and withdrawal. ${ }^{27}$ These rights were conceived as rights that cannot be transferred away from the authors and creators of works - and it cannot be a coincidence that the conception of these "moral rights" emerged just as corporate law evolved. As a result of the evolution of corporate law, the transfer of the earlier-conceived copyright rights (which were always conceived of as being transferable) could occur, by the end of the nineteenth century, not just between individuals (as had been the case up until the corporate law changes beginning in the mid-nineteenth century, since, before then, all businesses had comprised individuals) but also from individual creators and authors to separate corporate "persons" (and these latter, themselves, could never be original authors or creators).

Although some moral rights (the rights of paternity and integrity) were accepted into the international Berne Convention early on in the twentieth century, ${ }^{28}$ moral rights were never fully embraced or expressed in national legislation as quickly or to the extent that the earlier copyright protection had been. Indeed, the United States, with its fulsome 1787 constitutional expression of copyright and patent protection, has never fully embraced the notion of these Victorian-age moral rights ${ }^{29}$ and has been instrumental in keeping them out of expressions of intellectual property law in most international trade agreements. ${ }^{30}$

leaves the former intact." available online at http://global.oup.com/booksites/ content/9780198259466/15550027.

27 It is important in this context to note that, in the original French, the term "moral rights" does not carry the connotation of "ethical" that "moral" does in English; it simply connotes a relationship to an individual. See M.A. Wilkinson and N. Gerolami, "The Author as Agent of Information Policy: the Relationship between Economic and Moral Rights in Copyright" (2009) 26 Government Information Quarterly, 321-332 at 326. See, further, Margaret Ann Wilkinson, "The Public Interest in Moral Rights Protection" [2006] 1 Michigan State Law Rev, 193-234. See also Mistrale Goudreau, "Le droit moral de l'auteur au Canada, (1994) 25 R.G.D. 403 at 404.

28 As Article 6bis of Berne, through the Rome Conference of 1928.

29 As the United States did not join Berne for over a century after its inception (joining in 1989), the international discussion about moral rights that took place in the Berne Union in the early twentieth century was irrelevant to American international obligations.

30 When the text of Berne became a starting point for agreement about intellectual property in the context of modern international trade, in the 1990s, the United States omitted insistence upon deletion of the Berne text concerning 
Attempts to theorise moral rights protection in ways consistent with the original conception of the copyright monopolies have proven largely unsatisfactory. ${ }^{31}$ And, from a theoretical perspective, it can hardly be argued that non-transferable, individual rights (as moral rights are conceived to be) have a place in trade and therefore in a trade regime or trade agreements. ${ }^{32}$ Nonetheless they have endured in national copyright laws and in the public international forum of Berne, despite opposition to them such as that mounted by the United States.

The continuing widespread acceptance and endurance of the late nineteenth-century concept of moral rights can be explained by recognising their fundamental link with individuals. This link to individuals, and not corporate businesses, became attractive to societies after the nineteenth-century changes to business law separated the majority of businesses from individuals, leaving most business in the hands of corporations. Thus the emergence of the legally independent corporation compromised the continuing function of copyright as originally conceived: a mechanism linking individuals in society in their dual roles as producers (businesses) and consumers of information (see again Figure 1.1). With the emergence of the separation of legal "persons" into corporate and individual, the nexus between copyright as a private interest and the public interest needed to be re-examined - but this was never done explicitly. However, the emerging dominance of the corporate business structure over the older sole proprietorships and partnerships led to ownership of the original (economic) rights in copyright lying overwhelmingly with corporate interests. ${ }^{33}$ This, in turn, led many nations to recognise a need for new rights related to, but apart from, the economic

moral rights from the North American Free Trade Agreement between the Government of Canada, the Government of Mexico and the Government of the United States, 17 December 1972, Can TS No27, 32 ILM 289, 605 (entered into force 1 January 1994) [NAFTA] but did insist on the omission of Article 6bis of Berne, on moral rights, from the Trade-Related Aspects of Intellectual Property Rights Agreement (1994), 33 ILM 1197 [TRIPS]. The instantiation of moral rights in American domestic law is extremely limited, see, for example, the Visual Artists' Rights Act, 17 USC §106A (1990).

31 See again Wilkinson, and Wilkinson and Gerolami, supra note 27.

32 This is not to say, however, that the moral rights cannot have an economic impact in the broader context, as will be discussed next. And it should also be recalled that the original "bargain" embodied in the original triad of intellectual property devices was not without eventual economic reward for nations.

33 See Figure 1.2. 
rights in copyright: hence the rise of those rights eventually grouped as "the moral rights" (as illustrated in Figure 1.234).

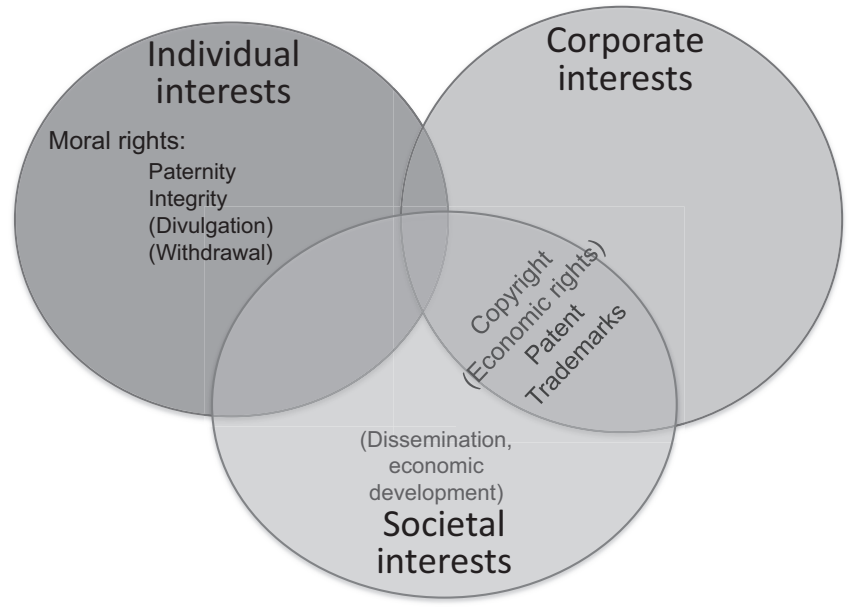

Figure 1.2 Moral rights take shape as copyright is increasingly corporatised

It can be argued that copyright rights, transferable as they are to corporations (and, indeed, vesting in corporations where the creator individuals are employees) continue to serve one of their original social purposes, namely enhancing the distribution of information in society. Moral rights, precisely because they are non-transferable and thus tied to an individual creator's identity, are increasingly necessary in the distributed, digital environment in order to meet the second information need of an information-seeking public (one that arises after the need for availability of information is satisfied): the need for indications of the authority of available information in order to judge its reliability. ${ }^{35}$ If the rights instantiated as moral rights were conceptualised strictly as, and limited only to, those rights that enhance information seekers' abilities to judge the authority of works in satisfying information needs, then such rights would be located in Figure 1.2 in the intersection between "Individual

34 The rights of divulgation and withdrawal are shown in brackets in Figure 1.2 because, although recognised by some nations, and proposed for inclusion in Berne, they did not become recognised in Berne.

35 This approach to moral rights analysis is in the two previous articles (Wilkinson, Wilkinson and Gerolami) cited above in note 27. 
interests" and "Societal interests". ${ }^{36}$ It is argued here that it is only if moral rights are located at this intersection that they should be considered part of the context of intellectual property. Currently, as presently instantiated in various jurisdictions, moral rights are not so strictly conceived.

\section{A LATER CONSEQUENCE OF NOT RE-CONCEPTUALISING INTELLECTUAL PROPERTY}

The rhetoric of a public interest in the perpetuation of monopolies over the use of patented inventions, copyright works and trademarks, ostensibly because of the monopolies' inherent service to the public in promoting information dissemination, reached its zenith in the twentieth century through the instantiation of these rights in the United Nations.

Several key public international law instruments that enshrine direct expressions of the public interest thought to be served by intellectual property rights were adopted in the twentieth century. For instance, the Universal Declaration of Human Rights (UDHR), adopted in 1948, states that

[E]veryone has the right freely to participate in the cultural life of the community, to enjoy the arts and to share in the scientific advancement and its benefits ... [E]veryone has the right to the protection of the moral and material interests resulting from any scientific, literary or artistic production of which he is the author. ${ }^{37}$

And then, later, in 1966, Article 15 of the International Convention on Economic, Social and Cultural Rights, ${ }^{38}$ in addition to providing for

... the right of everyone:

a. To take part in cultural life; [and]

b. To enjoy the benefits of scientific progress and its applications,

36 The author argues that there should be no moral right claimed in anonymity - although it may be an interest that should be instantiated in law for other reasons - because consumers can derive no evidence of the authority of a work if its author is not identified (see further the articles cited in note 27).

37 United Nations General Assembly. (1948) Universal Declaration of Human Rights, 10 December 1948, 217 A (III), art 27.

38 United Nations General Assembly. (1966) International Covenant on Economic, Social and Cultural Rights, 16 December 1966, United Nations, Treaty Series, vol 993, p. 3. 
also provided for "... the right of everyone ... c. To benefit from the protection of the moral and material interests resulting from any scientific, literary or artistic production of which he is the author." Despite these explicit expressions of inclusion of intellectual property as a human right - and the re-location of intellectual property's historic international governing structures into the primary international public law institution (the United Nations) ${ }^{39}$ - during the twentieth century, by the last quarter of the twentieth century, with the transition from the industrial age to the information age well underway, a concerted effort emerged amongst key industrialised nation states to shift intellectual property international standard formation into the realm of international trade law.

The late twentieth-century initiative to instantiate intellectual property in the international trade environment was largely successful by the end of that century: most notably, the new World Trade Organization (WTO $)^{40}$ that emerged from the post-World War II General Agreement on Trade and Tariffs (GATT) ${ }^{41}$ included a fulsome agreement governing intellectual property law $^{42}$ (whereas the earlier GATT had not dealt with intellectual property at all).

Paradoxically, since the newly created global international trade environment for intellectual property did not replace the older public international legal environment for intellectual property, an unusual international legal situation resulted: intellectual property now has both international trade agreement expression and international public law United Nations-centred expression.

It is argued here that one impetus for the development that placed intellectual property into the context of international trade is the lack of rigorous analysis of the effect of the growth of the corporation as the dominant business form and its consequent effect on intellectual property as originally conceived in the patent, copyright and trademark devices. This lack of analytic rigour is represented graphically in Figure 1.3.

Another consequence of the failure to focus on the increasing multidimensionality of intellectual property has been an increasingly polarised literature in the twenty-first century, with some analysts failing entirely to

39 Agreement between the United Nations and the World Intellectual Property Organization (entered into effect 17 December 1974), 956 UNTS 405, accessed 25 May 2018 at http://www.wipo.int/treaties/en/text.jsp?file_id=305623.

40 Marrakesh Agreement Establishing the World Trade Organization (1994) 33 ILM 1125.

41 General Agreement on Trade and Tariffs, concluded 30 October 1947, 61 Stat. A-11, 4 GATT BISDA (1969).

42 TRIPS, supra note 30. 


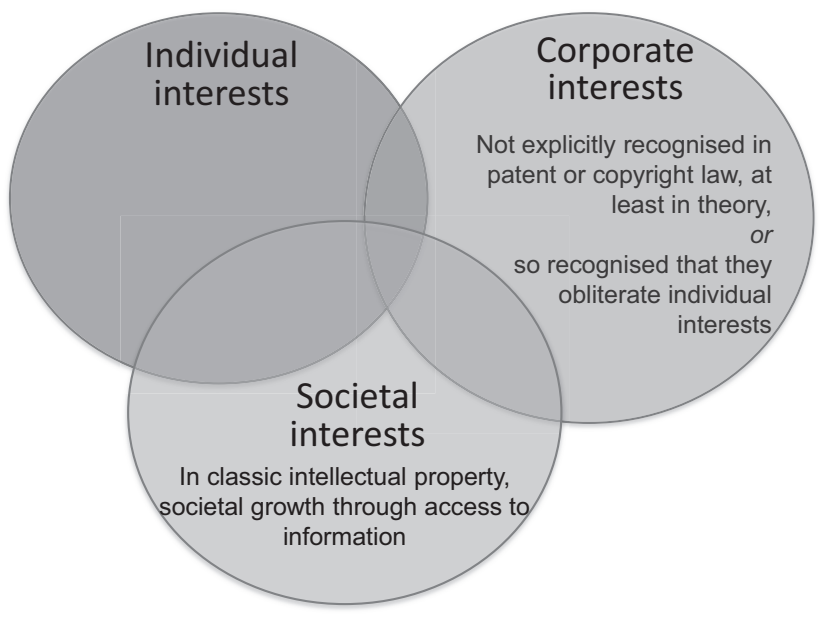

\section{Figure 1.3 The rise of the corporation changes the intellectual property landscape - but unexamined}

discuss individual interests and, instead, focusing exclusively on corporate interests while others focus exclusively on the apparent obliteration of individual interests. One author emblematic of the first school is Jane Ginsberg, ${ }^{43}$ who argued that it was not possible for an international treaty to be created focused entirely on limitations or exceptions to the rights of copyright holders. This argument was pre-empted in 2012 by the creation of the public international Treaty to Facilitate Access to Published Works by Visually Impaired Persons and Persons with Print Disabilities [Marrakesh Treaty]. ${ }^{44}$ An author arguably emblematic of the second school is John Perry Barlow. ${ }^{45}$ Both attitudes typically claim to be

43 See Jane Ginsburg, "Do Treaties Imposing Mandatory Exceptions to Copyright Violate International Copyright Norms?" 28 February 2012, Media Institute, https://www.mediainstitute.org./2012/02/28/do-treaties-imposing-mandatoryexceptions-to-copyright-violate-international-norms/.

44 The Marrakesh Treaty was adopted by the General Assembly of World Intellectual Property Organization on 27 June 2013 and in effect in Canada as of 30 September 2016, accessed 25 May 2018 at http://www.wipo.int/pressroom/en/ articles/2016/article_0007.html. See further Margaret Ann Wilkinson, "International Copyright: Marrakesh and the Future of Users' Rights Exceptions", in Mark Perry (ed.), Global Governance of Intellectual Property in the 21st Century, Cham, Switzerland: Springer (2016), 107-127.

45 See Perry Barlow, "The Economy of Ideas", accessed 25 May 2018 at www.wired.com/wired/archive/2.03/economy.ideas_pr.html. 
reflecting upon society's interests - indeed even the Preamble to the TRIPS Agreement states that protection of intellectual property has a public policy objective. ${ }^{46}$

\section{THE IMPORTANCE OF RE-CONCEPTUALISING}

It is not argued here that the involvement of corporate interests in intellectual property, and even the domination of corporate ownership interests over individual ownership interests in the classic intellectual property areas of patent, trademark and copyright, indicate an abdication of contribution to societal interests. It is argued here that it is the dominance of corporate ownership of classic intellectual property, worldwide, that has transformed the function of patent, trademark and copyright law from that originally conceived. Rather than agreeing with such authors as Adam Moore (who writes that "[T]he globalization of intellectual property, rapid growth of digital networks, and expanding power of multinational corporations, have pushed systems of intellectual property away from theoretical foundations and back towards privilege" $),{ }^{47}$ it is argued here that the shift from individual to corporate ownership of patents, copyrights and trademarks is the key challenge to understanding the current contribution of intellectual property to societal interests. This is so because modern intellectual property now functions amidst the triad of individual, corporate and societal interests, and not in the binary world of individual and societal interests in which it arose.

One specific example of the historical expansion of notions of intellectual property that occurred when intellectual property entered the international trade realm has been the immediate inclusion and clear articulation of protection of confidential information in intellectual property in the trade context. ${ }^{48}$ Article 39 of the TRIPS Agreement provides:

46 TRIPS, supra note 30: "Recognizing that intellectual property rights are private rights; Recognizing the underlying public policy objectives of national systems for the protection of intellectual property, including developmental and technological objectives; ...".

47 Adam Moore, "Intellectual Property: Theory, Privilege and Pragmatism" (2003) 16 Cdn J of Law and Jurisprudence 191 at 204.

48 The closest provision in the public law sphere is Article 10bis of Paris (1967), supra note 13, "protection against unfair competition", providing that

(2) Any act of competition contrary to honest practices in industrial or commercial matters constitutes an act of unfair competition. 
Natural and legal persons shall have the possibility of preventing information lawfully within their control from being disclosed to, acquired by, or used by others without their consent in a manner contrary to honest commercial practices so long as such information:

a) is secret in the sense that it is not, as a body or in the precise configuration and assembly of its components, generally known among or readily accessible to persons within circles that normally deal with the kind of information in question;

b) has commercial value because it is secret; and

c) has been subject to reasonable steps under the circumstances, by the person lawfully in control of the information, to keep it secret.

The phrase "a manner contrary to honest commercial practices" is defined in a footnote to the text of the TRIPS Agreement as "... at least practices such as breach of contract, breach of confidence and inducement to breach, and includes the acquisition of undisclosed information by third parties who knew, or were grossly negligent in failing to know, that such practices were involved in the acquisition".

The inclusion of "breach of contract" in this provision clearly takes the provision beyond the ambit of intellectual property and into contract law. Moreover, while protection of business confidences may be consistent with corporate interests in furthering opportunities for an intellectual property monopoly similar to patent protection, protection of business confidences is not consistent with society's interest in access to information that formed the basis of the original intellectual property devices (discussed above). Legal protection for confidences is legal protection of the right to censor - to stop information from being made available. And it is being instantiated in the international trade environment as a right of businesses, which are now predominately corporations.

The move to require protection of business confidences as part of intellectual property under an international agreement ${ }^{49}$ and bilateral

(3) The following in particular shall be prohibited:

i. all acts of such a nature as to create confusion ...

ii. false allegations in the course of trade ...

iii. indications or allegations ... liable to mislead the public ...

And, as discussed by this author previously, it is quite distant in nature. See Margaret Ann Wilkinson, "Confidential Information and Privacy-Related Law in Canada and in International Instruments", in Chios Carmody (ed.) Is Our House in Order? Canada's Implementation of International Law, Montreal \& Kingston: McGill-Queen's University Press (2010), 275.

49 TRIPS, supra note 30. 
trade agreements ${ }^{50}$ creates enforcement of certain censoring of information flow by requiring that such business information be legally continually protected from being made publicly available - this is the reverse of the classic intellectual property law approach which promotes dissemination of information to the public in exchange for creation of limited term monopolies.

The tacit ambiguity arising as intellectual property purports to expand into censorship of certain dissemination of information beyond corporate boundaries, rather than remaining a system specifically designed for the encouragement of dissemination of information throughout society, is highlighted by information developments in public international forums other than those which focus on intellectual property. The quintessential counter-movements to the movement to embed protection of business confidences and corporate data protection in intellectual property are twofold: the movement to seek legal recognition for the right of individuals to promote access to information held by organisations on the one hand, and, on the other hand, the movement to legally enshrine individuals' rights to personal privacy and personal data protection.

The legal focus on access to information has been played out in two different ways: first, many governments have adopted access legislation prohibiting government and public sector entities from keeping secrets other than as specifically legislated, and, second, many jurisdictions have created private sector business environments which legally require public or shareholder disclosure of prescribed business information.

The legal instantiation of privacy and personal data protection has also gained ground over the past fifty years. At the international level, these protections have been created through the aegis of two separate international public bodies. First, two fundamental instruments of the United Nations address privacy: the UDHR, ${ }^{51}$ Article 12 , states " $[\mathrm{N}]$ o one shall be subjected to arbitrary interference with his privacy ..." and the International Covenant on Civil and Political Rights, 52 provides in Article 17 that " $[\mathrm{N}]$ o one shall be subject to arbitrary or unlawful interference with his privacy ..." Second, personal data protection has been championed by the Organisation for Economic Co-operation and Development (OECD). Its Guidelines Governing the Protection of Privacy and Transborder Flows of Personal Data, a Recommendation of the OECD

50 NAFTA, supra note 30.

51 See note 37.

5216 December 1966, 999 UNTS 171, Can TS 1976 No 47, (1967) 61 ILM 368 . 
Council, was published in September of $1980 .{ }^{53}$ These 1980 Guidelines were specifically designed to accomplish two purposes simultaneously: (1) to protect personal data ${ }^{54}$ and (2) to ensure the free flow of data between countries. ${ }^{55}$

Analytically, the modern existence of such legal devices to provide legal protection, on the one hand, for privacy, and separately, on the other hand, for personal data, provide further evidence of the need to re-examine the nature of intellectual property and in particular to re-examine the claims that devices such as the protection of confidential information and data protection belong within the construct of intellectual property. ${ }^{56}$ See Figure 1.4.

53 See Organisation for Economic Co-operation and Development, Guidelines on the Protection of Privacy and Transborder Flows of Personal Data (Paris, 1981) at http://www.oecd.org/sti/ieconomy/oecdguidelinesontheprotection of privacyandtransborderflowofpersonaldata.htm. These original Guidelines were updated in 2013. See OECD Privacy Guidelines (2013) http://www.oecd.org/ internet/economy/privacy-guidelines.htm.

54 The 1980 Guidelines, para 2 concerning scope, referred to "personal data ... which ... pose a danger to privacy and individual liberties" but the operative sections, paras 7-14, do not mention privacy, referring throughout to the treatment of "personal data".

55 This latter objective was intended to address a concern that had emerged, in reaction to notions of data privacy that were developing in the $1970 \mathrm{~s}$, that enclosing information within nation states through "privacy" restrictions would doom information-poor countries to even less opportunity, relative to information-rich countries, in the emerging "computer age" than earlier - and that portability of data between states was very important to ensuring that all nations could participate in the anticipated information economy. See Colin Bennett, Regulating Privacy: Data Protection and Public Policy in Europe and the United States (Ithaca: Cornell University Press, 1992).

56 "Personal data protection" must be distinguished from the construct known as "data protection" being noted here. Known also as "data exclusivity," the concept of "data protection" has been instantiated in TRIPS, art 39.3, and is a protection given to entities which collect data in connection with testing done in relation to medicines. The modern existence of legal devices to protect privacy and personal data also beg the question whether all the rights currently claimed as moral rights deserve that status if moral rights are to be properly considered part of intellectual property. See Wilkinson, and Wilkinson and Gerolami, cited at note 27. See also Patrick Masiyakurima, "The Trouble with Moral Rights" (2005) 68 The Modern Law Review, 411-434 at 432. 


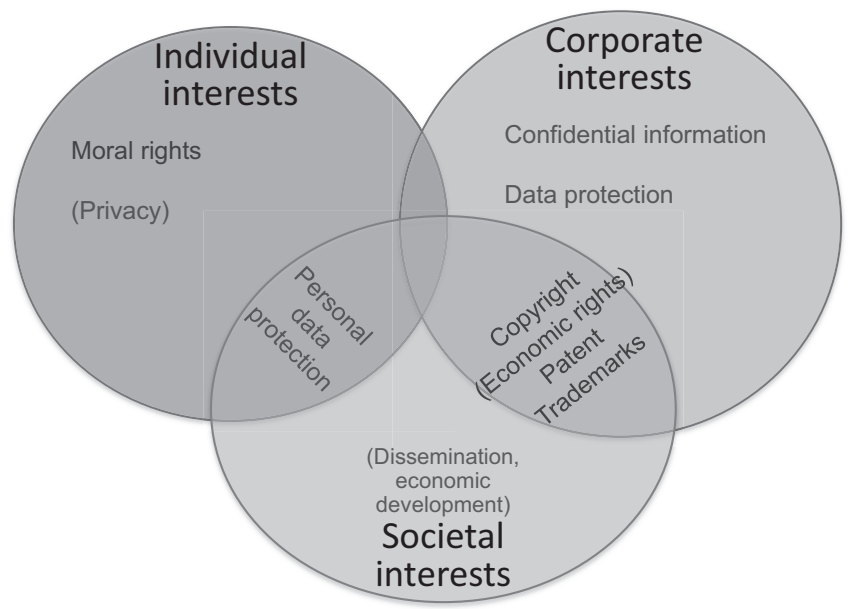

Figure 1.4 Tension and division created by separation of individuals from corporations (after creation of "original" intellectual property) intensifies

\section{AN ILLUSTRATION OF THE CURRENT CONCEPTUAL PROBLEMS}

In 2005, Canada's Federal Court of Appeal was faced with a conundrum: ${ }^{57}$ should copyright holders who had identified apparent infringers on the internet only in terms of their online identities (but not their actual, legal identities) be able to compel internet service providers (ISPs) to identify their subscribers to those alleging copyright infringement? In deciding the case, which involved the procedural question of compelling production of material held by a third party to the litigation, Justice Sexton, writing for himself, Noel, J, and Richard, CJ, was unequivocal:

Modern technology ... must not be allowed to obliterate those personal property rights which society has deemed important. Although privacy concerns must also be considered, it seems to me that they must yield to

57 BMG Inc v John Doe, 2005 FCA 193, [2005] 4 FCR 81 [BMG], affirming in part BMG Inc v John Doe, 2004 FC 488 (the latter heard by the Federal Court on 12 March 2004). 
public concerns for the protection of intellectual property rights in situations where infringement threatens to erode those rights. ${ }^{58}$

The Court, while recognising that "privacy concerns" deserved legal consideration, also unanimously prioritised intellectual property rights over "privacy concerns". This attitude meant prioritising corporate interests over individual interests. ${ }^{59}$ In taking this attitude, the Court failed to reflect fully the complexity of factors actually involved in the dispute between the litigants, ${ }^{60}$ whether in considering those involved on the motion (the

\author{
58 Ibid. at para 41. \\ 59 An approach followed by the Federal Court in Voltage Pictures LLC $v$
} John Doe and Jane Doe 2014 FC 161: Prothonotary Aalto ultimately found himself bound by the decision of the FCA in BMG (supra note 57). The facts in the 2014 Voltage Pictures case arose before the "notice and notice" revisions to Canada's Copyright Act (RSC 1985, c. C-42), described below in text accompanying note 67, came into force: the plaintiff contracted its forensic consultant Canipre to investigate potential infringers in 2012 and the case was heard 25 June 2013. This decision in the action identified in the Court Docket as T-2058-12 was followed several years later, after the coming into force of the "notice and notice" provisions, by another attempt by Voltage Pictures (and others) to launch a class action lawsuit (Court Docket \#T-662-16) in the same business context as the action Voltage Pictures had launched in 2012. The decision of Boswell J. in the second action (see Voltage Pictures LLC v John Doe, 2016 FC 881) noted the decision in the earlier action (at para 16) and held identifying information held by Internet Service Provider [ISP] Rogers should be released to the plaintiffs, but only after Rogers had been paid its fee. Voltage Pictures spearheaded an appeal to the Federal Court of Appeal. Stratas, JA, delivered the unanimous decision on the appeal (Voltage Pictures LLC v John Doe, 2017 FCA 97 (released 9 May 2017)) approving the order below with the exception that Rogers was not entitled to the fee ordered in the court below. Rogers then appealed the question of its entitlement to fees to the Supreme Court of Canada (Rogers Communications Inc v Voltage Pictures et al, Court file 37679) and was given leave by the Court to appeal (November 23, 2017). On September 14, 2018, the full Supreme Court (Brown, J, writing for the majority, with Côté, J concurring) reversed the Federal Court of Appeal insofar as it disallowed Rogers' fees (2018 SCC 38) and remitted the setting of the amount of those fees to the motions judge.

60 One might also be critical of Justice Sexton's apparent elision of the concept of "property rights" with the concept of "intellectual property rights" - a common confusion which is further examined in Margaret Ann Wilkinson, "The Confidentiality of Seclusion: Studying Information Flows to Test Intellectual Property Paradigms", Chapter 3 in Courtney Doagoo et al. (eds) Intellectual Property for the 21st Century: Interdisciplinary Perspectives on Intellectual Property Law, Toronto: Irwin Law (2014), 72-94, available at http://www.irwin law.com/content_commons/intellectual_property_21st_century. 
copyright holder plaintiffs to the action and the ISP intermediaries involved in providing service to the defendants) or those involved in the main action (the copyright holder plaintiffs and the alleged infringing defendants).

Figure 1.5 captures the complexity of the multiplicity of interests involved in such disputes and the intersecting of legal devices that are involved within each area of interests and within the intersections between them. The issue in $B M G$ arose squarely at the intersection of all three interests: individual, corporate and societal.

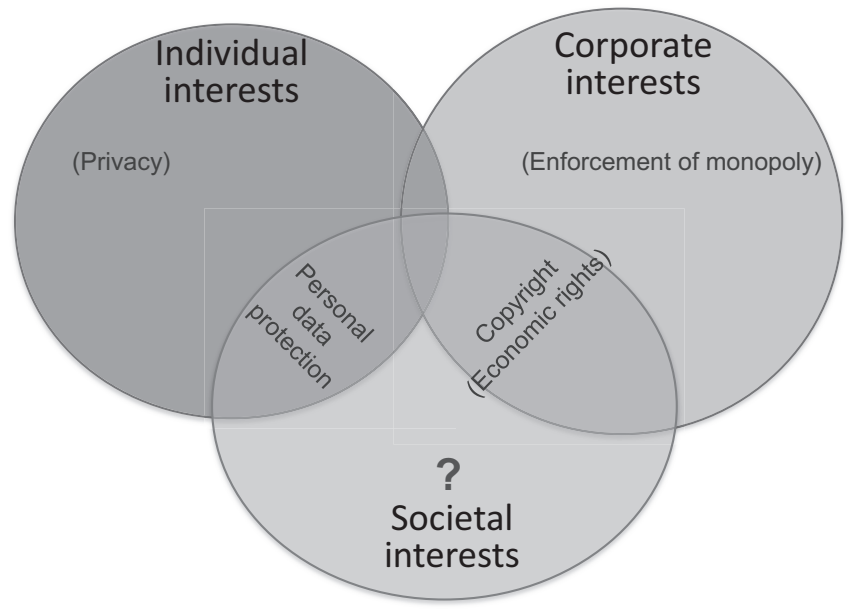

Figure 1.5 An intellectual property-related example requiring balancing amongst societal interests, individual interests and corporate interests

In $B M G,{ }^{61}$ in the contest between "legitimate privacy concerns" and intellectual property rights, the "legitimate privacy concerns" were identified with the fifth branch of the non-statutory test for granting equitable bills of discovery, a test which was found to be applicable for determining equitable discovery under Canada's Federal Court rule at issue. ${ }^{62}$

It should be noted that while, prior to 2004, there was no personal data protection legislation in Canada applicable to the scenario in $B M G$, in its

61 Supra note 57, interpreting Rule 238.

62 In Voltage Pictures (supra note 59), the Federal Court of Appeal acknowledged that the Court's earlier decision in $B M G$ was the leading case in the area before the more recent "notice and notice" regime was enacted in Canada in 2015 (the regime discussed below beginning at text accompanying note 67): see paras 17,18 and 59 . 
$2005 B M G$ decision, the Federal Court of Appeal was aware of, and acknowledged, sweeping federal legislation then newly governing personal data protection held by organisations in Canada's private sector, the Personal Information Protection and Electronic Documents Act (PIPEDA). ${ }^{63}$ The Court, however, did not fully incorporate that legislation into its reasoning. ${ }^{64}$

In its decision, the Federal Court of Appeal did note s 7(3) of PIPEDA, which states specifically that

\section{Disclosure without knowledge or consent}

For the purpose of clause 4.3 of Schedule 1, and despite the note that accompanies that clause, an organization may disclose personal information without the knowledge or consent of the individual only if the disclosure is

(c) required to comply with a subpoena or warrant issued or an order made by a court, person or body with jurisdiction to compel the production of information, or to comply with rules of court relating to the production of records;

In restricting its analysis of PIPEDA to this section, the Court did not give due consideration to the personal data protection provided by the statute. While s 7(3)(c) does allow for disclosure of personal information subject to a court order, the Court should have given due consideration to the entirety of PIPEDA when determining whether the "public interests [are] in favour of disclosure", the fifth element of the test for granting equitable discovery pursuant to Rule 238. Taking the full extent of the protection provided by PIPEDA into account, particularly its purpose as articulated in s 3 , one must conclude that the Court erred in its balancing of rights in the public interest. ${ }^{65}$

63 SC 2000, c. 5.

64 See Wilkinson, "The Confidentiality of Seclusion", supra note 60.

65 PIPEDA s.3 provides:

The purpose of this Part is to establish, in an era in which technology increasingly facilitates the circulation and exchange of information, rules to govern the collection, use and disclosure of personal information in a manner that recognizes the right of privacy of individuals with respect to their personal information and the need of organizations to collect, use or disclose personal information for purposes that a reasonable person would consider appropriate in the circumstances.

See further, M.A. Wilkinson, "Battleground between New and Old Orders: Control Conflicts between Copyright and Personal Data Protection", in Ysolde Gendreau (ed.) Emerging Intellectual Property Paradigm - Perspectives from Canada [Queen 
Subsequently, in 2012, with the passage of the Copyright Modernization Act, ${ }^{66}$ Canada amended its Copyright Act to specifically deal with the question of copyright enforcement in the internet context by introducing a statutory "notice and notice" regime ${ }^{67}$ - but this regime only came into force in 2015.68 Canada's "notice and notice" regime appears to be unique amongst nations. It is a system whereby a copyright holder can identify Internet Protocol addresses associated with infringing activity and, by approaching the relevant ISPs, send electronic letters through to the alleged infringers. The relevant ISPs are charged under the Copyright Act with ensuring, on behalf of rights holders, that such letters are delivered through to the alleged infringers. The anonymity of the alleged infringers is preserved by their ISPs - but the messages from the rights holders alleging infringement are delivered. Implementation of the system has appeared to curb piracy. ${ }^{69}$

Voltage Pictures v John Doe, decided by Canada's Federal Court in $2016,{ }^{70}$ was the first decision in this area to reach the Federal Court of Appeal $^{71}$ after both PIPEDA and Canada's Copyright Act "notice and notice" process had come into force in Canada.

At the outset of its judgment on appeal, the Federal Court of Appeal characterised the new "notice and notice" regime as a way to "lift the cloak of anonymity and reveal the identity of the suspected infringers so

Mary Studies in Intellectual Property series edited by Uma Suthersanen], Cheltenham, UK and Northampton, MA: Edward Elgar (2008), 227-266.

66 SC 2012, c. 20.

67 See Copyright Act (supra note 59), ss 41.25-41.27. Such a system may be contrasted with the "notice and takedown" approach of the American and European legislators. Under a "notice and takedown" system copyright holders send requests to online services providers to take down allegedly infringing content from their websites. The online service providers then must inform the alleged infringer and that subscriber can then dispute the alleged infringement.

68 Order Fixing the Day that is Six Months after the Day on which this Order is published as the Day on which Certain Provisions of the Copyright Act Come into Force, PC 2014-675, 12 June 2014, SOR/2014-58, Canada Gazette, Part II, vol 148, no 14, 2 July 2014.

69 Internet Security Task Force, Six Strikes and You're (Not Even Close To) Out; Internet Security Task Force Calls for End of Copyright Alert System, Cision PR Newswire, accessed 25 May 2018 at http://www.prnewswire.com/ news-releases/six-strikes-and-youre-not-even-close-to-out-internet-security-taskforce-calls-for-end-of-copyright-alert-system-300082007.html.

70 Supra note 59.

71 Ibid. None of the panel of the Federal Court of Appeal that heard $B M G$ formed part of the panel of the Federal Court of Appeal that decided Voltage Pictures. 
that the copyright owners can act to protect their rights". ${ }^{72}$ It explained the relationship between the older, continuing, Federal Court Rules regime (under which $B M G$ had been decided) and the new procedural regime in the Copyright Act:

The legislative ["notice and notice"] regime [in the Copyright Act] is designed to reduce the complications and answer many of the questions that can arise when a Norwich order [the old regime] is sought. In this way, [the "notice and notice" regime] makes the process more administrative in nature, more predictable, simpler and faster, to the benefit of all involved - but most of all to copyright owners who need to protect and vindicate their rights. ${ }^{73}$

The Court of Appeal acknowledged that the new "notice and notice" regime goes beyond the older regime: "The [Copyright Act's] legislative regime ... [puts] suspected infringers on notice so that they may cease any further infringing conduct." 74 On the other hand, the Court identified clearly the way in which the older Norwich order process works with the new "notice and notice" regime to complement and complete its effectiveness: "by not regulating the act of disclosure [of the identity of the suspected infringers to the copyright owner], the legislative regime does not displace the Norwich order process entirely. The Norwich order process remains to govern disclosure." ${ }^{5}$ It continued: “... Parliament elected to keep the courts in charge of deciding whether disclosure should be made and, if so, on what conditions ... to ensure that at the end of the process the courts can deal with any unfairness arising ..." 76

In terms of the multifactorial analysis that is the focus of this chapter, the Federal Court of Appeal's decision in Voltage Pictures is reactionary, clinging to earlier, binary conceptions of the goals of copyright, and reiterating (from Canada's Supreme Court in a 2002 copyright decision) the concept of "a balance between promoting the public interest in the encouragement and dissemination of works of the arts and intellect" (societal interests) and "obtaining a just reward for the creator." 77 The Federal Court of Appeal in Voltage Pictures continued its adoption of earlier expressions of the rights of creators by quoting from the Supreme Court in 2004 on the need: "to prevent someone other than the creator

\footnotetext{
72 Ibid. at para 3.

73 Ibid. at para 21.

74 Ibid. at para 22.

75 Ibid. at para 56.

76 Ibid. at para 57.

77 Ibid. at para 25 quoting Binnie, J, for the majority in Galerie d'art du Petit

Champlain inc c Théberge 2002 SCC 34 at para 30.
} 
from appropriating whatever benefits may be generated". ${ }^{78}$ In using the language simply of "creators" - and not distinguishing between individual creators and the corporate "persons" that form the modern core of Canada's economy - the Federal Court of Appeal in Voltage Pictures re-affirmed a misleading conception of "creators" as the holders of economic rights in copyright. In reality, in the modern corporate context, s 13(3) of Canada's Copyright Act operates to ensure that few economic rights, even initially, accrue to the benefit of individual creators:

Where the author of a work was in the employment of some other person under a contract of service or apprenticeship and the work was made in the course of his employment by that person, the person by whom the author was employed shall, in the absence of any agreement to the contrary, be the first owner of the copyright ... ${ }^{79}$

The binary approach taken in 2017 by the Federal Court of Appeal (in Voltage Pictures) to the interests involved in the modern copyright regime ignores the reality, discussed above, that it is largely only in the case of the moral rights that "creators" have ongoing interests in their creations. Indeed, it is only in 1931, through the addition of its first moral rights provision, that rights in Canada were actually re-identified with the creators in copyright ${ }^{80}$ after the separate identities of corporations in law were confirmed by the end of the nineteenth century. Indeed, Canada's Parliament has again recently recognised the need to augment the rights of creators, as opposed to those of economic rights holders, by extending the ambit of moral rights beyond just creators of works to performers. ${ }^{81}$

Nowhere in its Voltage Pictures judgment does the Federal Court of Appeal consider the extension of moral rights in Canada in 2012 when it opines on the "balance" in the Copyright Act. Indeed, in the concluding paragraph of its section on "[t]he purpose of the legislative regime", 82 whereas it had earlier been using the term "creator", the Federal Court of Appeal moves to the term "copyright owners": "the legislative regime must be interpreted to allow copyright owners to protect and vindicate their rights as quickly, easily and efficiently as possible while ensuring

78 Ibid. at para 25 quoting McLachlin, CJ, for the full Court in CCH v Law Society of Upper Canada, supra note 10, at para 23.

79 Supra note 59.

$8021 \& 22$ Geo.V., ch. 8 (Can.)

81 Supra note 59, ss 17.1, 17.2 (added in 2012).

82 Supra note 59 at paras 21-27. 
fair treatment for all" (emphasis added). By doing so, the Court de facto changes its focus to the "Corporate interests" circle in Figure 1.5 above.

The Federal Court of Appeal's notion of fairness is explicitly further explored at para 33: "[The ISP forwarding the notice of claimed infringement] furthers the objective of fairness to suspected infringers online: among other things, they may be able to oppose any later disclosure order ... by contacting the copyright owners ... They may also cease their infringing activities." This phraseology would seem to presuppose that the "suspected infringers" are, in fact, infringers. Where, in this formulation, is the "fair" outcome of the process for those who are wrongly suspected by the initiating rights holders of infringing? The Court continues its apparent identification of "suspected infringers" with "infringers" by commenting that

... leaving the cost of [notice and notice processes] with internet service providers, at least for the time being, is not unfair. After all, depending on the elasticity of demand, the costs can be passed on to the subscribers of the products of internet service providers, some of whom are the suspected infringers (emphasis added). ${ }^{83}$

What is "fair" about passing the costs of attempts at enforcement to all users of the internet, especially if those attempts turn out to be wrongheaded because the "suspected infringers" are not, in fact, infringing?

It is key to note that, in the judgment, the Federal Court of Appeal never explicitly balances the rights held by copyright holders against the privacy interests of the ISP subscribers. As merely suspected infringers, these individuals may not, in fact, be infringing at all. Even if infringement can be demonstrated in the end, is it appropriate to prioritise the rights of the rights holders in enforcement of their copyright interests over the rights of individuals to their privacy? In $R v$ Spencer, Justice Cromwell of the Supreme Court of Canada stated, for the Court, the following regarding an individual's privacy interest in her or his online identity:

In my view, the identity of a person linked to their use of the Internet must be recognized as giving rise to a privacy interest beyond that inherent in the person's name, address and telephone number found in the subscriber information ... Similarly, subscriber information, by tending to link particular

83 Supra note 59 at para 49. 
kinds of information to identifiable individuals, may implicate privacy interests relating not simply to the person's name or address but to his or her identity as the source, possessor or user of that information. ${ }^{84}$

At best, the Federal Court of Appeal in Voltage Pictures might arguably have been attempting to create a binary balance between individual and corporate interests (though it really focused on corporate interests). However, the Court made no attempt to weigh either of these (individual or corporate interests) in terms of the separate societal interests of ensuring that copyright preserves monopolies only insofar as they serve the public interest in access to information. The appeal judgment focuses on the appropriateness of the lower court's order for fees to be paid to ISP Rogers. Justice Stratas characterizes the purpose of the "notice and notice" regime as one which "makes the process more administrative ..., more predictable, simpler and faster, to the benefit of all involved - but most of all to copyright owners who need to protect and vindicate their rights." 85 In the context of the appeal before it, the Federal Court of Appeal in Voltage Pictures made no attempt to ensure that access to information was appropriately balanced with the rights of individuals to privacy. Indeed, the Court failed to address privacy at all - even though Canada's Supreme Court, as quoted above, in Spencer, had already flagged that issue as a key concern in the Internet environment.

\section{WHERE DO WE GO FROM HERE?}

Each new technology highlights again the tensions that were created in respect of the original intellectual property devices (for the protection of patents, copyrights and trademarks) when individuals were given the opportunity for identities separate from their businesses - and then both corporate businesses and individuals were given legal recognition as "persons". It is these tensions, it has been argued here, that actually spawned the numerous claimants for "intellectual property status" which have arisen since: moral rights, protection of business confidences, and data protection. However, each of these new claimants has actually represented a claim for information control - for an ability to censor the flow of information in society - rather than for the classic "balance" created by the three original intellectual property devices (a limited marketplace monopoly in return for dissemination of information).

\footnotetext{
$84 \quad R v$ Spencer, 2014 SCC 43 at para 47.

85 Voltage Pictures, note 59, per Stratas, JA, at para 21.
} 
The rise of each of the new claimants, it is argued, should be interpreted as highlighting modern problems within the classic triad of intellectual property devices (patent, copyright, trademark) that have been occurring since businesses evolved to represent almost exclusively corporate interests. Businesses virtually exclusively now represent the economic interests in intellectual property - including the newer areas of protection such as protection of business confidences and data protection, while only ownership of moral rights is reserved uniquely to individuals.

The foregoing discussion illustrates that evolving technology is merely a catalyst which reveals the systemic underlying tensions in the law, not the cause of the fundamental unrest in intellectual property circles. The cause of the tension in intellectual property is the rise of the corporation as an identity in its own right separate from the identities of individuals. Balance in intellectual property now has to be achieved in an environment of a triad of interests (individual, corporate and societal) and not as in the original intellectual property environment of dual interests (individual and societal). Once it is recognised that these are problems created by the rise of the corporation as a legal person, separate and apart from individuals, the real problems current in patent, copyright and trademark law can be addressed. As well, any further expansion of the rubric of intellectual property to embrace other devices (i.e. moral rights, protection of business confidences, and data protection) should be contemplated only if there is a demonstrated three-way balance between individuals, society and corporations. 